\title{
A COMPARISON OF THE ENVIRONMENTAL IMPACT OF SOLAR POWER GENERATION USING MULTICRYSTALLINE SILICON AND THIN FILM OF AMORPHOUS SILICON SOLAR CELLS: CASE STUDY IN THAILAND
}

\author{
Wasin Khaenson', Somchai Maneewan ${ }^{1 *}$, Chantana Punlek \\ 1 Department of Physics, Faculty of Science, Naresuan University, Phitsanulok, 65000, Thailand \\ * Corresponding author's e-mail: somchaim@nu.ac.th
}

Received: 2017.05 .15 Accepted: 2017.06.03 Published: 2017.07.01

\begin{abstract}
This paper studies the environmental impact of two different forms of solar power generation in Thailand - that of multicrystalline silicon solar cells, and that of thin film amorphous silicon solar cells. It takes as its study two of the largest solar cell power plants of their kind in Thailand; a multicrystalline silicon plant in the north (generating $90 \mathrm{MW}$ ) and a thin film amorphous silicon plant in the centre (generating $55 \mathrm{MW}$ ). The Life Cycle Assessment tool (LCA) was used to assess the environmental impact of each stage of the process, from the manufacture of the cells, through to their transportation, installation and eventual recycling. The functional unit of the study was the generation of $1 \mathrm{kWh}$ of power transmitted and distributed by the Electricity Generating Authority of Thailand (EGAT) and Provincial Electricity Authority (PEA). The environmental impact results were calculated in terms of eco-points $(\mathrm{Pt})$ per functional unit of $1 \mathrm{kWh}$. The characterised data for $1 \mathrm{kWh}$ of solar power generation was then compared with data for $1 \mathrm{kWh}$ of combined cycle and thermal power generation (both in Thailand), using the same set of characterisation factors. After analyzing the results, both forms of solar power energy generation were found to impact upon the studied categories of Human Health, Ecosystem Quality and Resource Depletion, whilst also highlighting the importance of the solar cell module recycling process in decreasing the overall environmental impact. When the two solar cell technologies were compared, the overall impact of the multicrystalline silicon solar cell was found to be higher than that of the thin film amorphous silicon solar cell. Furthermore, when assessing the overall impact against non-renewable power generating technologies such as combined cycle and thermal power generation, the thin film amorphous silicon solar cells were found to have the lowest environmental impact of all technologies studied.
\end{abstract}

Keywords: solar power generation, life cycle assessment, multicrystalline silicon solar cell, amorphous silicon solar cell

\section{INTRODUCTION}

Tropical regions have a clear potential to generate significant quantities of power from solar energy. This is especially true in Thailand, where the central and northeastern regions experience high levels of solar radiation throughout the year. Compared to other countries, Thailand's levels of solar radiation give it the greatest solar potential in the region - in 2015 it measured $17.8 \mathrm{MJ} / \mathrm{m}^{2}$.day - and globally Thailand comes close to matching such countries as Australia and the United States [Netherlands Embassy in Bangkok 2016]. Since 2010, the country has sought to capitalize upon this natural advantage, and has begun to significantly increase its total solar energy capacity, as can be seen in Figure 1 [Terry and Tanokkorn 2014].

By 2015, almost one sixth of Thailand's renewably generated power came from solar energy $-1,419.58 \mathrm{MW}$ of a total renewable capacity of 7,962.8 MW. Analyzing the country regionally, 


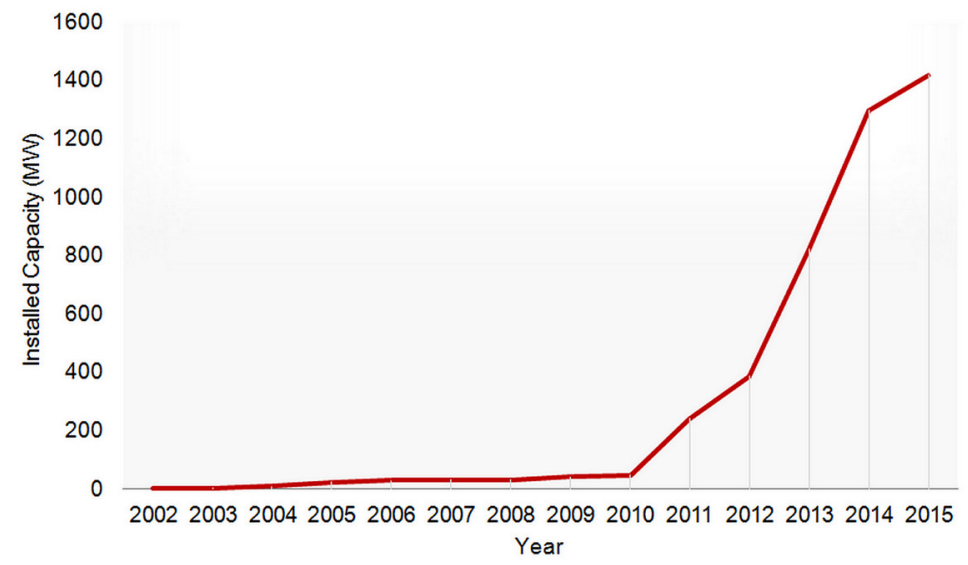

Figure 1. The total installed capacity of power generation by using solar energy 2002-2015

the centre was by far the most productive, generating almost half the country's solar power, 538.31 MW. This was followed by the north, which generated $484.98 \mathrm{MW}$, and the northeast, generating 396.25 MW. These three regions were the most productive because they enjoy year round levels of high solar radiation. By contrast, the south experiences high levels of rainfall for eight months a year and consequently generated a mere 0.04 MW from solar energy [DEDE 2015].

In the centre of Thailand, the greatest amount of power (175.28 MW) was generated in Lop Buri province. Lop Buri province is home to largest power plant in the region, which uses thin film amorphous silicon (a-Si) solar cells to generate $55 \mathrm{MW}$. In the north of Thailand, the province of Nakhon Sawan generated the greatest amount of power (232.45 MW). Nakhon Sawan contains the Thailand's largest solar cell power plant, which in contrast to the central plant, uses multicrystalline silicon (m-Si) solar cells and generates 90 MW. In the northeast, the greatest amount of solar power was generated in Nakhon Ratchasima province (81.08 MW), and, in the south, all of the region's solar power is generated by four power plants in Phuket, Krabi, Trang and Songkhla province, each generating $0.1 \mathrm{MW}$ (see Fig. 2.) [Khaenson et al. 2016a].

Solar energy is considered to have a low impact upon the environment when compared to traditional forms of power generation, such as fossil fuels. However, low as it may be, there is still an impact and this can vary greatly depending upon the type of technology used - in particular the environmental impact caused by the manufacture, deployment and operation of photovoltaic (PV) solar cells. At present, most prominent is the use of multicrystalline silicon solar cells and thin film amorphous silicon solar cells, of the types used in the northern and central solar cell plants respectively. This study therefore focuses on evaluating and contrasting the environmental impact of power generation from these two solar cell technologies, using the aforementioned northern and central plants as case studies.

In order to fully assess the environmental impact of a technology, information must be gathered upon the materials, designs, manufacturing processes, product use and disposal of said products [Hendrickson et al. 1998]. This study uses Life Cycle Assessment (LCA) as a tool to provide this information. This is a technique that evaluates the environmental aspects of a product system through all stages of its life cycle, thus creating a more accurate picture of the environmental trade-offs in product and process selection, and ensuring a more accurate decision making process [Azapagic 1999, Reno et al. 2011, Theodosiou 2005]. A typical LCA consists of four stages [ISO 2006a, b, Jensen et al. 1997, Meyer et al. 2009, Weidema 2000], the first being Goal and Scope Definition, the second being Life Cycle Inventory (LCI). LCI involves a detailed life cycle inventory analysis, with compilation of data about both energy and resource use, and on emissions to the environment throughout the life cycle. The third LCA stage is the Life Cycle Impact Assessment (LCIA) which assesses the potential impacts associated with the identified forms of resource use and environmental emissions. Lastly, the fourth stage, Interpretation, is the interpretation of the results from the previous phases of the study in relation to the objectives of the study. 


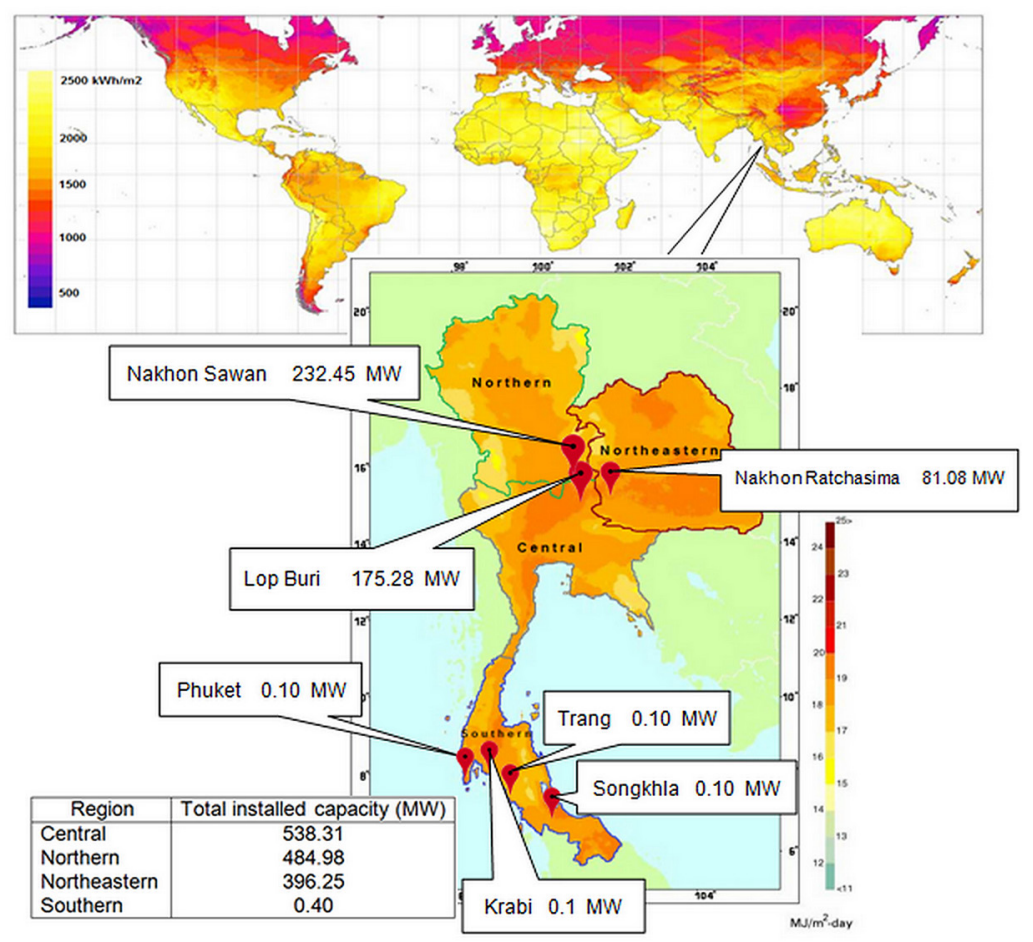

Figure 2. Installed capacity of solar power generation in each regions of Thailand

\section{MATERIALS AND METHODS}

\section{Goal and scope definition}

The aim of this study was to assess and compare the environmental impact of solar cell power generation using two different types of cell; multicrystalline silicon solar cells and thin film amorphous silicon solar cells. The Life Cycle Assessment (LCA) tool was used to measure the environmental impact at each stage of the power generation process. Two power plants were studied; one plant in northern Thailand which used multicrystalline silicon solar cells and generating $90 \mathrm{MW}$, and one in central Thailand using thin film amorphous silicon solar cells and generating $55 \mathrm{MW}$. Both plants were the largest of their kind in Thailand. The most important specifications are given in Table 1. The power generated was transmitted and distributed by the Electricity Generating Authority of Thailand (EGAT) and Provincial Electricity Authority (PEA).

\section{Functional unit}

The functional unit used for this study was $1 \mathrm{kWh}$ of power generated by the solar cell power plant. The environmental impact results were calculated in terms of $\mathrm{Pt}$ per functional unit of $1 \mathrm{kWh}$.

\section{Allocation}

When assessing the environmental impact of power generation it was important that every stage of the process was taken into account. For example, in addition to the process of converting sunlight to electricity via solar cell modules, it was important that the impact of manufacturing, transporting and recycling these modules was also analyzed [Chamsilpa et al. 2010].

\section{System boundaries}

The system boundaries of solar power generation were divided into four main stages; module manufacturing, transportation, installation, and recycling (see Fig. 3).

The initial stage, module manufacturing, involved the manufacture of the solar cells, and their assembly into solar cell modules. Life Cycle Assessment for module production encompassed all stages, from silicon production to module assembling [Yue et al. 2014]. The system boundary of module manufacturing consisted of silicon production (mining and refining of silica, reduction of silica to silicon, and production of high purity silicon), casting (casting and sawing of silicon), wafer production, cell processing (etching/ texturing, emitter formation, metallization, passivation and antireflective coating), and module 
Table 1. Specifications of solar cell power plants studied

\begin{tabular}{|l|c|c|}
\hline \multicolumn{1}{|c|}{ Description } & Northern Solar Cell Power Plant & Central Solar Cell Power Plant \\
\hline Type of module & Multicrystalline silicon & Thin film amorphous silicon \\
Nominal output (Wp) & $245 \mathrm{~W}$ & $135 \mathrm{~W}$ \\
Module weight & $18.5 \mathrm{~kg}$ & $26 \mathrm{~kg}$ \\
Module dimensions & $1636 \times 986 \times 35 \mathrm{~mm}$ & $1402 \times 1001 \times 24 \mathrm{~mm}$ \\
Open circuit voltage & $37.1 \mathrm{~V}$ & $61.3 \mathrm{~V}$ \\
Short circuit current & $8.63 \mathrm{~A}$ & $3.41 \mathrm{~A}$ \\
Voltage at Pmax & $37.1 \mathrm{~V}$ & $47 \mathrm{~V}$ \\
Current at Pmax & $8.63 \mathrm{~A}$ & $2.88 \mathrm{~A}$ \\
Max. system voltage & $1000 \mathrm{~V}$ & $1000 \mathrm{~V}$ \\
Number of modules & $508794 \mathrm{modules}$ & $540000 \mathrm{modules}$ \\
Power plant area & $7308 \mathrm{Acres}$ & $4740 \mathrm{Acres}$ \\
Total power generated & $198,467,069 \mathrm{kWh} / \mathrm{year}$ & $114,000,000 \mathrm{kWh} / \mathrm{year}$ \\
Total power consumption & $762,196 \mathrm{kWh} / \mathrm{year}$ & $565,000 \mathrm{kWh} / \mathrm{year}$ \\
Total water consumption & $20,043.02 \mathrm{~m} / \mathrm{year}$ & $5,728.5 \mathrm{~m} 3 / \mathrm{year}$ \\
Plant irradiation & $5.22 \mathrm{kWh} / \mathrm{m}^{2} / \mathrm{day}$ & $5.55 \mathrm{kWh} / \mathrm{m}^{2} / \mathrm{day}$ \\
Main transformers & $22 / 115 \mathrm{kV}, 50 \mathrm{MVA}, 3$ Units & $40,000 \mathrm{~kW}, 50 \mathrm{MVA}, 2$ Units \\
Transformers & $400 / 22 \mathrm{kV}, 1.25 \mathrm{MVA}, 90$ Units & $2,500 \mathrm{kVA}, 2 \mathrm{MW}, 27$ Units \\
Inverters & $500 \mathrm{~kW}, 180$ Units & $250 \mathrm{~kW}, 220$ Units \\
\hline
\end{tabular}

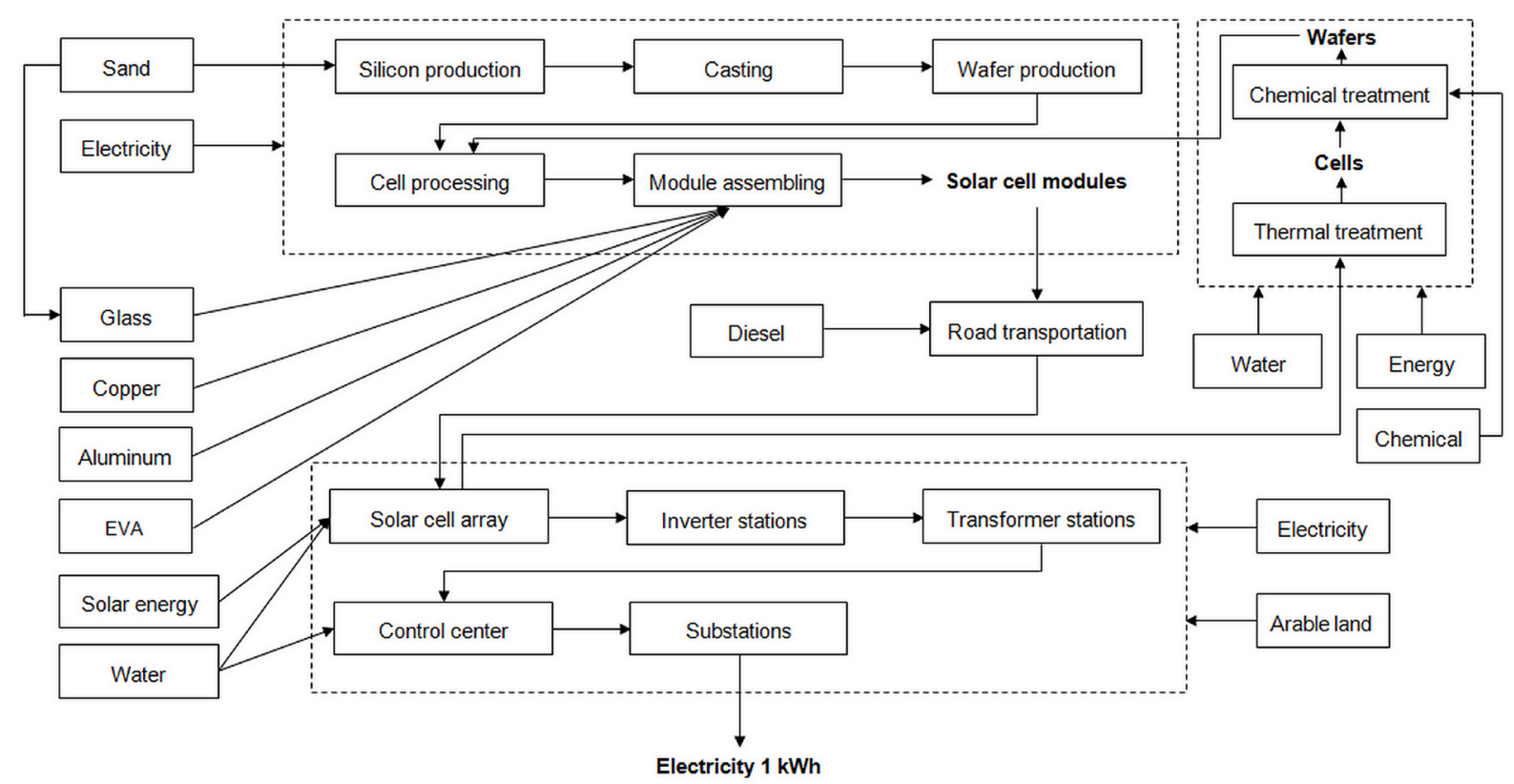

Figure 3. The system boundary of electricity generation from solar energy.

assembling (module production, module testing and electricity testing) [Stoppato 2008].

Transportation is the process whereby the solar cell modules were conveyed from manufacturer to power plant by 10 -wheel trucks. Fuel consumption of these vehicles and environmental emissions were accounted for. The diesel consumption rate for 10 -wheel trucks is 26.18 liter $/ 100 \mathrm{~km}$. The environmental emissions from diesel consumption $\left(\mathrm{CO}_{2}, \mathrm{CO}, \mathrm{CH}_{4}\right.$, $\mathrm{NO}_{\mathrm{x}}, \mathrm{N}_{2} \mathrm{O}$ and NMVOC) measured 3.1924, 0.03059, $0.000219,0.03642,0.000109$, and $0.00692 \mathrm{~kg} /$ liter respectively [http://www.ertc.deqp.go.th/ertc/images/ stories/ user/ct/ERTC20Y/CarbonLabel.pdf].
Installation is the process of generating power from the solar cell modules in the solar cell power plant. The system boundary of power generation comprises of the solar cell array (to convert the solar energy into direct current), inverter stations (to convert the direct current into alternating current), transformer stations (to transform the voltages of alternating current to the appropriate level), a control center (to monitor and control all stages of the process), and substations (to connect and switch the electricity lines and to change the voltage) [Fraas and Partain 2010, Khaenson et al. 2016b]. 
The final stage, recycling, is where solar panels which have reached the end of their useful life are disassembled and the wafers and other components are recovered and reused in the production of new modules or other products. This is preferable to panel disposal through incineration or at landfill sights which has a high environmental impact. The system boundary includes thermal treatment (burning off the laminate, metallization, and anti-reflection coating) and chemical treatment [Müller et al. 2005].

\section{Life cycle impact assessment (LCIA) method}

All stages of the solar cell power generation process were analyzed using the Eco - indicator 99 method to assess the environmental impact. This methodology studies the impact of a process on three distinct areas: the damage to Human Health, the damage to Ecosystem Quality, and the impact upon Resource Depletion [Goedkoop and Spriensma 2000, ISO 2000].

The Human Health damages are measured in DALYs. This is short for Disability Adjusted Life Years. A damage of 1 means one life year of one individual is lost, or with a weight of 0.25 one person suffers four years from a disability. This category comprises of studies on carcinogenesis, respiratory effects on humans caused by both organic and inorganic substances, climate change, ionising radiation and ozone layer depletion [Havelaar 2007]. The Ecosystem Quality damages are measured in terms of $\mathrm{PDF}^{*} \mathrm{~m}^{2 *} \mathrm{yr}$. PDF is short for Potentially Disappeared Fraction of Species, and measures the species loss (extinction rate) in an area of land over a period of time. A rating of one means all species disappear from one $\mathrm{m}^{2}$ during one year. The study of ecosystem quality is comprised of ecotoxic emissions, the combined effect of acidification and eutrophication, and land occupation and land conversion. Lastly, Resource Depletion measures the extraction of minerals and fossil fuels. Damage is measured in terms of MJ surplus energy, and represent the surplus energy needed for future extractions of mineral and fossil fuels [Goedkoop et al. 2001].

So that these damage categories could be properly compared, the various units were then aggregated into a single environmental impact function, known as an eco-indicator. This was done by using a set of dimensionless weighting factors, with the final result being measured in terms of eco-points (Pt) [Henryk 2011].

\section{RESULTS AND DISCUSSION}

\section{Life Cycle Inventory (LCI)}

In the module manufacturing stage, input and output data was obtained from solar cell power plant surveys, published literature and research undertaken into solar cell modules [Chamsilpa et al. 2010, Stoppato 2008, Phylipsen and Alsema 1995].

Tables 2 and 3 show the data used in the analysis of production of multicrystalline and thin film amorphous silicon solar cell modules, per $\mathrm{kWh}$ power generated.

In the transportation stage, input and output data was, again, obtained from solar cell power plant surveys and published literature [Chamsilpa et al. 2010]. The solar cell modules were transferred from the place of manufacture to the solar cell power plant by 10 -wheel trucks. The dimensions of a 10 -wheel truck are $2.35 \times 7.10 \mathrm{x}$ $2.40 \mathrm{~m}$ (see Fig. 4), whilst the solar cell module dimensions are $1636 \times 986 \times 35 \mathrm{~mm}$ for multicrystalline silicon and $1402 \times 1001 \times 24 \mathrm{~mm}$ for thin film amorphous silicon. Therefore, one truck can transport 702 multicrystalline modules and 1,189 thin film amorphous modules at one time. The distance from manufacturer to the northern solar cell plant was 189 kilometers, whilst the central solar cell plant was 152 kilometers from the manufacturer. Table 4 shows fuel consumption and environmental emissions from conveying the modules.

In analyzing the installation stage, input and output data was obtained from solar energy power plant surveys (system studies, material measurement and accounting). Table 5 lists the data used in the analysis of $1 \mathrm{kWh}$ of power generation from solar energy. It should be noted that at the solar cell array stage, the northern and central solar cell power plants have notably different results. This is owing to the two plants use of different designs of solar cell array to generate their power. Only multicrystalline cells require an electrical input, and this results in the emission of nitrogen, oxygen, water vapor, nitric oxide, nitrogen dioxide and $\mathrm{NO}_{\mathrm{x}}$. None of these gases are produced in the central plant because thin film amorphous cells require no such electrical input.

In the recycling stage, input and output data was obtained from solar cell power plant surveys, published literature and research undertaken into recycling solar cell modules. The contribution from the thermal and chemical processes, 
Table 2. Input and output associated with production of multicrystalline silicon solar cell module per kWh power generated from solar energy

\begin{tabular}{|c|c|c|c|}
\hline Description & Process & Unit & Quantity \\
\hline \multicolumn{4}{|l|}{ Materials } \\
\hline Quartz & Silicon production & $\mathrm{kg}$ & 1.16E-02 \\
\hline Charcoal & Cell processing & $\mathrm{kg}$ & $1.56 \mathrm{E}-03$ \\
\hline Low Ash Coal & Cell processing & $\mathrm{kg}$ & $2.30 \mathrm{E}-03$ \\
\hline Cokes & Cell processing & $\mathrm{kg}$ & $1.56 \mathrm{E}-03$ \\
\hline Wood scrap & Cell processing & $\mathrm{kg}$ & $3.41 \mathrm{E}-03$ \\
\hline Silane Tetra Chloride & Silicon production & $\mathrm{kg}$ & $3.04 \mathrm{E}-04$ \\
\hline Argon & Casting & $\mathrm{kg}$ & $1.48 \mathrm{E}-03$ \\
\hline Mineral oil & Wafer production & $\mathrm{kg}$ & 3.16E-03 \\
\hline $\mathrm{SiC}$ & Wafer production & $\mathrm{kg}$ & 4.06E-03 \\
\hline $\mathrm{KOH}$ & Wafer production & $\mathrm{kg}$ & $3.28 \mathrm{E}-03$ \\
\hline $\mathrm{HNO}_{3}$ & Wafer production & $\mathrm{kg}$ & $1.56 \mathrm{E}-04$ \\
\hline $\mathrm{POCl}_{3}$ & Wafer production & $\mathrm{kg}$ & $2.46 \mathrm{E}-05$ \\
\hline $\mathrm{HF}$ & Wafer production & $\mathrm{kg}$ & $2.79 \mathrm{E}-04$ \\
\hline $\mathrm{CF}_{4}$ & Wafer production & $\mathrm{kg}$ & 2.05E-05 \\
\hline Al/Ag-paste & Wafer production & $\mathrm{kg}$ & 1.97E-04 \\
\hline Ag-paste & Wafer production & $\mathrm{kg}$ & 2.87E-05 \\
\hline $\mathrm{SiH}_{4}$ & Cell processing & $\mathrm{kg}$ & $8.20 \mathrm{E}-06$ \\
\hline $\mathrm{NH}_{3}$ & Cell processing & $\mathrm{kg}$ & $3.28 \mathrm{E}-05$ \\
\hline $\mathrm{N}_{2}{ }^{3}$ & Cell processing & $\mathrm{kg}$ & 4.10E-04 \\
\hline Sn-coated Cu-strips & Module assembling & $\mathrm{kg}$ & 1.23E-04 \\
\hline EVA foil & Module assembling & $\mathrm{kg}$ & 4.39E-03 \\
\hline Chem. hardened glass & Module assembling & $\mathrm{kg}$ & $3.22 \mathrm{E}-02$ \\
\hline Tedlar/AI/Tedlar & Module assembling & $\mathrm{kg}$ & $6.15 \mathrm{E}-04$ \\
\hline Al (in Tedlar) & Module assembling & $\mathrm{kg}$ & $8.20 \mathrm{E}-07$ \\
\hline Polyester & Module assembling & $\mathrm{kg}$ & $2.99 \mathrm{E}-03$ \\
\hline Silicon adhesive & Module assembling & $\mathrm{kg}$ & 2.63E-04 \\
\hline Aluminum & Module assembling & $\mathrm{kg}$ & $8.12 \mathrm{E}-03$ \\
\hline Polysulphide elastomer & Module assembling & $\mathrm{kg}$ & 1.44E-03 \\
\hline \multicolumn{4}{|l|}{ Emissions to air } \\
\hline Dust & Silicon production & $\mathrm{kg}$ & 4.10E-07 \\
\hline $\mathrm{CO}_{2}$ & Cell processing & $\mathrm{kg}$ & 1.85E-02 \\
\hline $\mathrm{SO}_{2}$ & Wafer production & $\mathrm{kg}$ & $6.56 \mathrm{E}-05$ \\
\hline Si dust & Cell processing & $\mathrm{kg}$ & 4.92E-05 \\
\hline Argon gas & Silicon production & $\mathrm{kg}$ & 1.46E-03 \\
\hline & Casting & $\mathrm{kg}$ & $3.90 \mathrm{E}-04$ \\
\hline Solvents & Cell processing & $\mathrm{kg}$ & 4.51E-05 \\
\hline \multicolumn{4}{|l|}{ Emissions to water } \\
\hline $\mathrm{CaCl}_{2}$ & Silicon production & $\mathrm{kg}$ & $3.90 \mathrm{E}-04$ \\
\hline $\mathrm{KOH}^{2}$ & Wafer production & $\mathrm{kg}$ & $1.30 \mathrm{E}-03$ \\
\hline $\mathrm{KCl}$ & Wafer production & $\mathrm{kg}$ & 1.60E-03 \\
\hline $\mathrm{NaNO}_{3}$ & Wafer production & $\mathrm{kg}$ & 1.11E-04 \\
\hline $\mathrm{NaH}_{2} \mathrm{PO}_{4}$ & Wafer production & $\mathrm{kg}$ & 1.63E-05 \\
\hline $\mathrm{NaOCl}$ & Wafer production & $\mathrm{kg}$ & 2.46E-05 \\
\hline $\mathrm{NaF}$ & Wafer production & $\mathrm{kg}$ & $6.15 \mathrm{E}-05$ \\
\hline \multicolumn{4}{|l|}{ Solid waste } \\
\hline $\mathrm{SiO}_{2}$ & Cell processing & $\mathrm{kg}$ & $1.64 \mathrm{E}-04$ \\
\hline $\mathrm{CaF}_{2}^{2}$ & Wafer production & $\mathrm{kg}$ & $2.38 \mathrm{E}-04$ \\
\hline Contaminated Si & Wafer production & $\mathrm{kg}$ & $2.26 \mathrm{E}-04$ \\
\hline Rejected cells & Module assembling & cell & $1.31 \mathrm{E}-02$ \\
\hline Ethylene vinyl acetate & Module assembling & $\mathrm{kg}$ & 2.01E-04 \\
\hline Silicon adhesive & Module assembling & $\mathrm{kg}$ & $8.20 \mathrm{E}-06$ \\
\hline Polysulphide elastomer & Module assembling & $\mathrm{kg}$ & 1.15E-04 \\
\hline Rejected modules & Module assembling & $\mathrm{kg}$ & 4.51E-04 \\
\hline Module waste & Module assembling & $\mathrm{kg}$ & $2.22 \mathrm{E}-02$ \\
\hline \multicolumn{4}{|l|}{ Other waste } \\
\hline Si (in mineral oil) & Wafer production & $\mathrm{kg}$ & $2.34 \mathrm{E}-03$ \\
\hline $\mathrm{SiC}$ & Wafer production & $\mathrm{kg}$ & $4.20 \mathrm{E}-03$ \\
\hline Mineral oil & Wafer production & $\mathrm{kg}$ & $3.04 \mathrm{E}-03$ \\
\hline
\end{tabular}


Table 3. Input and output associated with production of thin film amorphous silicon solar cell module per kWh power generated from solar energy

\begin{tabular}{|l|c|c|c|}
\hline \multicolumn{1}{|c|}{ Description } & Process & Unit & Quantity \\
\hline Material & Silicon production & $\mathrm{kg}$ & low \\
Silicon & Module assembling & $\mathrm{kg}$ & $1.01 \mathrm{E}-01$ \\
Glass & Module assembling & $\mathrm{kg}$ & $6.55 \mathrm{E}-03$ \\
Aluminum & Module assembling & $\mathrm{kg}$ & $1.82 \mathrm{E}-03$ \\
$\mathrm{EVA}$ & Module assembling & $\mathrm{kg}$ & $7.90 \mathrm{E}-04$ \\
Copper & Silicon production & $\mathrm{kWh}$ & $3.43 \mathrm{E}-01$ \\
Electricity & & & \\
Emission to air & Module assembling & $\mathrm{kg}$ & \\
$\mathrm{CO}_{2}$ & Module assembling & $\mathrm{kg}$ & \\
$\mathrm{CH}_{4}$ & Silicon production & $\mathrm{kg}$ & \\
$\mathrm{SO}_{2}$ & Silicon production & $\mathrm{kg}$ & \\
$\mathrm{NO}_{\mathrm{x}}$ & Silicon production & $\mathrm{kg}$ & \\
$\mathrm{PM}$ & & & \\
\end{tabular}
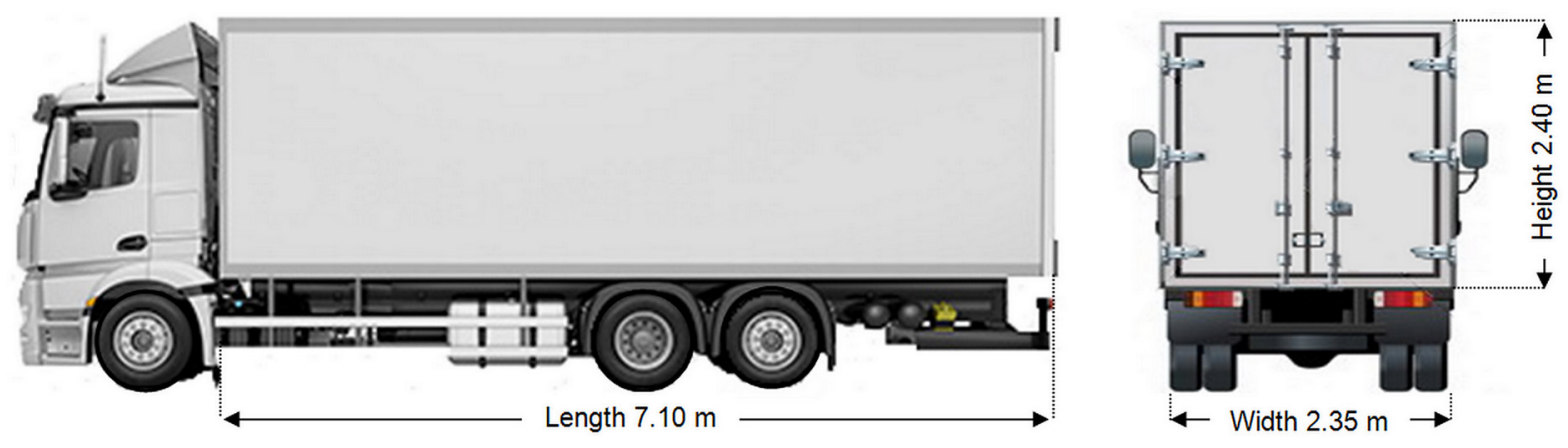

Figure 4. The dimensions of a 10-Wheel Truck

Table 4. Fuel consumption and environmental emissions from conveyed modules per $\mathrm{kWh}$ of power generation

\begin{tabular}{|l|c|c|c|}
\hline \multicolumn{1}{|c|}{ Description } & Unit & m-Si solar cell power plant & a-Si solar cell power plant \\
\hline $\begin{array}{l}\text { Fuel consumption } \\
\text { Diesel }\end{array}$ & Liter & & \\
Emission & & $1.81 \mathrm{E}-04$ & $1.59 \mathrm{E}-04$ \\
$\mathrm{CO}$ & $\mathrm{kg}$ & $5.79 \mathrm{E}-04$ & $5.08 \mathrm{E}-04$ \\
$\mathrm{CO}$ & $\mathrm{kg}$ & $5.54 \mathrm{E}-06$ & $4.86 \mathrm{E}-06$ \\
$\mathrm{CH}$ & $\mathrm{kg}$ & $3.96 \mathrm{E}-08$ & $3.48 \mathrm{E}-08$ \\
$\mathrm{NO}_{x}$ & $\mathrm{~kg}$ & $6.59 \mathrm{E}-06$ & $5.79 \mathrm{E}-06$ \\
$\mathrm{~N}_{2} \mathrm{O}$ & $\mathrm{kg}$ & $1.97 \mathrm{E}-08$ & $1.73 \mathrm{E}-08$ \\
$\mathrm{NMVOC}$ & $\mathrm{kg}$ & $1.25 \mathrm{E}-06$ & $1.10 \mathrm{E}-06$ \\
\hline
\end{tabular}

the recycling of glass and aluminium, as well as the reuse of recovered wafers were all investigated. Table 6 shows that by recycling and reusing the material of old photovoltaic cells, there is a significant decrease in both energy consumption and material consumption. By constructing solar panels from old cells there is an energy saving of around a $1 / 3$ when compared to using new materials [Richard 2008]. Furthermore approximately $90 \%$ of the glass in an old cell can be recycled and used in new glass products [Monier and Hestin 2011]. Of the other recyclable materials, it was possible to reuse approximately $86.5 \%$ of them [Anctil and Fthenakis 2012].

\section{Environmental Impact Assessment}

Table 7 summarizes the characterised results for $1 \mathrm{kWh}$ of power generation from solar energy. The environmental impact can be detailed as follows:

In the northern plant, the manufacturing of the multicrystalline silicon solar cells had a negative impact upon the following categories - respiration of inorganic substances, climate change, acidification and eutrophication, and extraction of both mineral and fossil fuels. The second stage, transportation, negatively impacted the following - respiration of organic and inorganic sub- 
Table 5. Input and output associated with installation of solar cell modules per kWh power generated from solar cell power plant

\begin{tabular}{|c|c|c|c|c|c|c|}
\hline Description & Unit & Solar cell array & Inverter stations & Transformer stations & Control center & Substations \\
\hline \multicolumn{7}{|c|}{$\begin{array}{l}\text { m-Si solar cell plant } \\
\text { Input }\end{array}$} \\
\hline Solar energy & kWh & $4.87 E+00$ & 0 & 0 & 0 & 0 \\
\hline Electricity & kWh & $2.00 \mathrm{E}-04$ & 10.7E-04 & 7.10E-04 & $9.50 \mathrm{E}-04$ & $9.20 \mathrm{E}-04$ \\
\hline Water & $\mathrm{cm}^{3}$ & $7.31 \mathrm{E}+01$ & 0 & 0 & $2.79 \mathrm{E}+01$ & 0 \\
\hline Arable land & $\mathrm{m}^{2}$ & $1.48 \mathrm{E}-02$ & $1.61 \mathrm{E}-05$ & 8.06E-06 & 4.03E-05 & 4.84E-05 \\
\hline $\mathrm{CO}_{2}$ & $\mathrm{~kg}$ & 1.66E-04 & 7.74E-04 & $5.17 \mathrm{E}-04$ & 6.96E-04 & $6.66 \mathrm{E}-04$ \\
\hline $\mathrm{CH}_{4}^{2}$ & $\mathrm{~kg}$ & $0.68 \mathrm{E}-05$ & 3.10E-05 & 2.07E-05 & $2.79 \mathrm{E}-05$ & $2.66 \mathrm{E}-05$ \\
\hline $\mathrm{N}_{2}{ }^{4}$ & $\mathrm{~kg}$ & $0.17 \mathrm{E}-02$ & $0.89 \mathrm{E}-02$ & $0.60 \mathrm{E}-02$ & $0.80 \mathrm{E}-02$ & $0.77 \mathrm{E}-02$ \\
\hline $\mathrm{O}_{2}$ & $\mathrm{~kg}$ & $0.30 \mathrm{E}-03$ & 1.61E-03 & 1.07E-03 & $1.43 \mathrm{E}-03$ & 1.38E-03 \\
\hline Water Vapor & $\mathrm{kg}$ & $0.11 \mathrm{E}-03$ & $0.61 \mathrm{E}-03$ & $0.41 \mathrm{E}-03$ & $0.54 \mathrm{E}-03$ & $0.53 \mathrm{E}-03$ \\
\hline NO & $\mathrm{kg}$ & $0.20 \mathrm{E}-07$ & $1.08 \mathrm{E}-07$ & $0.72 \mathrm{E}-07$ & $0.96 \mathrm{E}-07$ & $0.93 \mathrm{E}-07$ \\
\hline $\mathrm{N}_{2} \mathrm{O}$ & $\mathrm{kg}$ & $0.16 \mathrm{E}-08$ & $0.87 E-08$ & $0.58 \mathrm{E}-08$ & $0.77 \mathrm{E}-08$ & $0.75 \mathrm{E}-08$ \\
\hline $\mathrm{NO}_{x}$ & $\mathrm{~kg}$ & $0.33 \mathrm{E}-07$ & $1.74 \mathrm{E}-07$ & 1.16E-07 & $1.55 \mathrm{E}-07$ & $1.50 \mathrm{E}-07$ \\
\hline \multicolumn{7}{|l|}{$\begin{array}{l}\text { a-Si solar cell plant } \\
\text { Input }\end{array}$} \\
\hline Solar energy & kWh & $9.46 \mathrm{E}+00$ & 0 & 0 & 0 & 0 \\
\hline Electricity & $\mathrm{kWh}$ & 0 & 1.67E-03 & 1.14E-03 & $0.83 E-03$ & 1.32E-03 \\
\hline Water & $\mathrm{cm}^{3}$ & $4.74 \mathrm{E}+01$ & 0 & 0 & $2.88 E+00$ & 0 \\
\hline $\begin{array}{l}\text { Arable land } \\
\text { Output }\end{array}$ & $\mathrm{m}^{2}$ & $1.67 \mathrm{E}-02$ & $2.81 \mathrm{E}-05$ & $1.41 \mathrm{E}-05$ & $4.21 \mathrm{E}-05$ & 5.61E-05 \\
\hline $\mathrm{CO}_{2}$ & $\mathrm{~kg}$ & $0.16 \mathrm{E}-04$ & 12.1E-04 & $8.29 \mathrm{E}-04$ & 6.06E-04 & $9.56 \mathrm{E}-04$ \\
\hline $\mathrm{CH}_{4}^{2}$ & $\mathrm{~kg}$ & $0.06 \mathrm{E}-05$ & 4.84E-05 & 3.31E-05 & $2.43 \mathrm{E}-05$ & 3.82E-05 \\
\hline $\mathrm{N}_{2}$ & $\mathrm{~kg}$ & 0 & $1.40 \mathrm{E}-02$ & $0.96 \mathrm{E}-02$ & $0.70 \mathrm{E}-02$ & 1.10E-02 \\
\hline & $\mathrm{kg}$ & 0 & $2.52 \mathrm{E}-03$ & $1.72 \mathrm{E}-03$ & $1.26 \mathrm{E}-03$ & 1.99E-03 \\
\hline Water Vapor & $\mathrm{kg}$ & 0 & $0.96 \mathrm{E}-03$ & $0.65 \mathrm{E}-03$ & $0.48 \mathrm{E}-03$ & $0.75 \mathrm{E}-03$ \\
\hline NO & $\mathrm{kg}$ & 0 & 1.69E-07 & 1.16E-07 & $0.84 \mathrm{E}-07$ & 1.33E-07 \\
\hline $\mathrm{N}_{2} \mathrm{O}$ & $\mathrm{kg}$ & 0 & $0.14 \mathrm{E}-07$ & $0.09 \mathrm{E}-07$ & $0.07 \mathrm{E}-07$ & $0.11 \mathrm{E}-07$ \\
\hline $\mathrm{NO}_{x}$ & $\mathrm{~kg}$ & 0 & $2.72 \mathrm{E}-07$ & $1.86 \mathrm{E}-07$ & $1.36 \mathrm{E}-07$ & $2.15 \mathrm{E}-07$ \\
\hline
\end{tabular}

Table 6. Input and output associated with recycling of solar cell modules per $\mathrm{kWh}$ power generated from solar cell power plant

\begin{tabular}{|l|c|c|c|c|c|}
\hline \multicolumn{1}{|c|}{ Description } & Unit & $\mathrm{m}-\mathrm{Si}$ & Ref. & a-Si & Ref. \\
\hline Material & $\mathrm{kg}$ & $-3.66 \mathrm{E}-02$ & [Anctil and Fthenakis 2012] & $-9.07 \mathrm{E}-02$ & [Wambach et al. 2009] \\
Glass & $\mathrm{kg}$ & $-7.50 \mathrm{E}-04$ & [Anctil and Fthenakis 2012] & Low & [Wambach et al. 2009] \\
$\mathrm{Si}$ & $\mathrm{kg}$ & $-6.58 \mathrm{E}-04$ & [Olson et al. 2013] & $-2.62 \mathrm{E}-06$ & [Wambach et al. 2009] \\
Aluminum & $\mathrm{kWh}$ & $-3.81 \mathrm{E}-02$ & [Müller et al. 2005] & $-1.97 \mathrm{E}-01$ & [Wambach et al. 2009] \\
Electricity & $\mathrm{kg}$ & $-1.06 \mathrm{E}-02$ & [Müller et al. 2005] & $-5.49 \mathrm{E}-02$ & [Wambach et al. 2009] \\
Emission to air & $\mathrm{kg}$ & $-2.18 \mathrm{E}-05$ & [Müller et al. 2005] & $-1.13 \mathrm{E}-04$ & [Wambach et al. 2009] \\
$\mathrm{CO}_{2}$ & $\mathrm{~kg}$ & $-3.74 \mathrm{E}-05$ & [Müller et al. 2005] & $-1.87 \mathrm{E}-05$ & [Wambach et al. 2009] \\
$\mathrm{CH}_{4}$ & $\mathrm{~kg}$ & $-5.42 \mathrm{E}-05$ & [Müller et al. 2005] & $-2.71 \mathrm{E}-05$ & [Wambach et al. 2009] \\
$\mathrm{SO}_{2}$ & $\mathrm{~kg}$ & $-2.34 \mathrm{E}-07$ & [Müller et al. 2005] & $-1.72 \mathrm{E}-06$ & [Wambach et al. 2009] \\
$\mathrm{NOx}$ & &
\end{tabular}

stances, climate change, acidification and eutrophication, and extraction of fossil fuels. During this stage, all environmental impact categories were the result of $\mathrm{CO}_{2}, \mathrm{CO}, \mathrm{CH}_{4}, \mathrm{NO}_{x}, \mathrm{~N}_{2} \mathrm{O}$, and NMVOC emissions from diesel consumption to convey the solar cell modules from manufacturer to power plant. The installation stage had a negative impact upon respiration of organic and inorganic substances, climate change, acidification and eutrophication, and land use. Lastly, the effect of recycling was to significantly decrease the environmental impact on climate change, acidifi- cation and eutrophication, the respiration of inorganic substances, organic substances, and the extraction of minerals, measuring $45.60 \%, 30.71 \%$, $17.69 \%, 9.15 \%$, and $2.96 \%$ respectively.

With regard to the impact categories effected, the central solar cell power plant differed to the northern plant only with respect to the module manufacturing process, where there was an additional impact upon the respiration of organic substances and ecotoxicity, but none upon the extraction of fossil fuels. The impact of transportation and installation remained comparable. Likewise, 
Table 7. Characterised results for $1 \mathrm{kWh}$ of power generation from solar energy

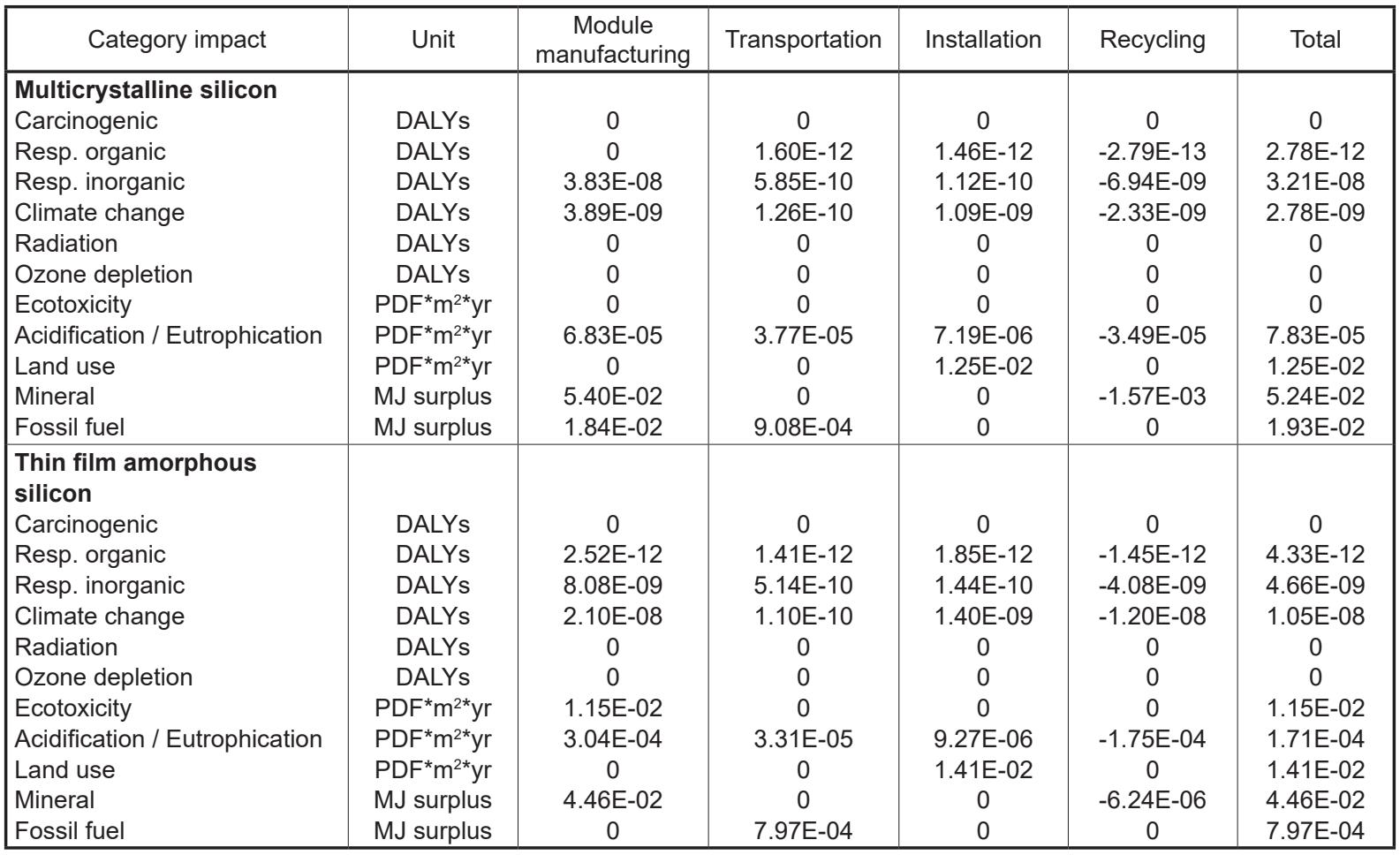

the recycling process decreased environmental impacts on identical impact categories, this time measuring $53.33 \%, 50.57 \%, 46.68 \%, 25.09 \%$, and $0.02 \%$ respectively.

In order to compare the various environmental impact categories, the data was scaled to $100 \%$ (see Fig. 5) and aggregated into a single environmental impact function - the eco-point $(\mathrm{Pt})$ indicator.

Figure 6 shows the subdivision of the environmental index by impact category and comparison of both solar cell types. The following can be concluded with respect to the contribution of each process to the impact categories considered in this study:

In the module manufacturing stage, the extraction of minerals was the main impact category. This was the result of the high quantities of aluminum and copper used in the module assembly process, the silicon and mineral oil used for wafer production and the quartz used for silicon production. The environmental impact of producing multicrystalline silicon solar cells was higher than that of thin film amorphous silicon solar cells, which measured 2.84E-03 Pt and 2.75E$03 \mathrm{Pt}$ respectively. In multicrystalline cells, the wafers must be built from a single piece of highpurity silicon crystal, a process which is energy intensive and time consuming [Tsuo et al. 1999]. Amorphous cells by contrast, do not require this rigid crystalline framework and consequently have a much simpler, and cheaper, manufacturing process. As the name suggests, they are also incredibly thin and are measured in millionths of an inch. This results in a significant saving in materials - with manufacture requiring around $1 / 300$ as much material as multicrystalline cells [Davies 2013].

In the transportation stage, the extraction of fossil fuels was the main impact categories due to diesel consumption. The environmental impact of transporting cells to the northern plant was marginally higher because the plant was 37 kilometers further from the manufacturer.

In the installation stage, the greatest impact category was found to be land use, due to the vast amounts of arable land needed to construct the power plant and erect the arrays. Of the two plants, the central plant had a significantly greater impact, ostensibly because of the lower conversion efficiency of thin film amorphous cells [Alsema 2006]. Such cells typically operate at around $7-13 \%$ efficiency, meaning that they require up to four times the amount of space that multicyrstalline cells do [Davies 2013]. In terms of land use, the central plant measured 1.67E-02 $\mathrm{m}^{2}$ whilst the northern plant had a lesser impact of $1.49 \mathrm{E}-02 \mathrm{~m}^{2}$. In terms of eco-indicator, this equated to $1.14 \mathrm{E}-03 \mathrm{Pt}$ and 9.92E-04 Pt respec- 


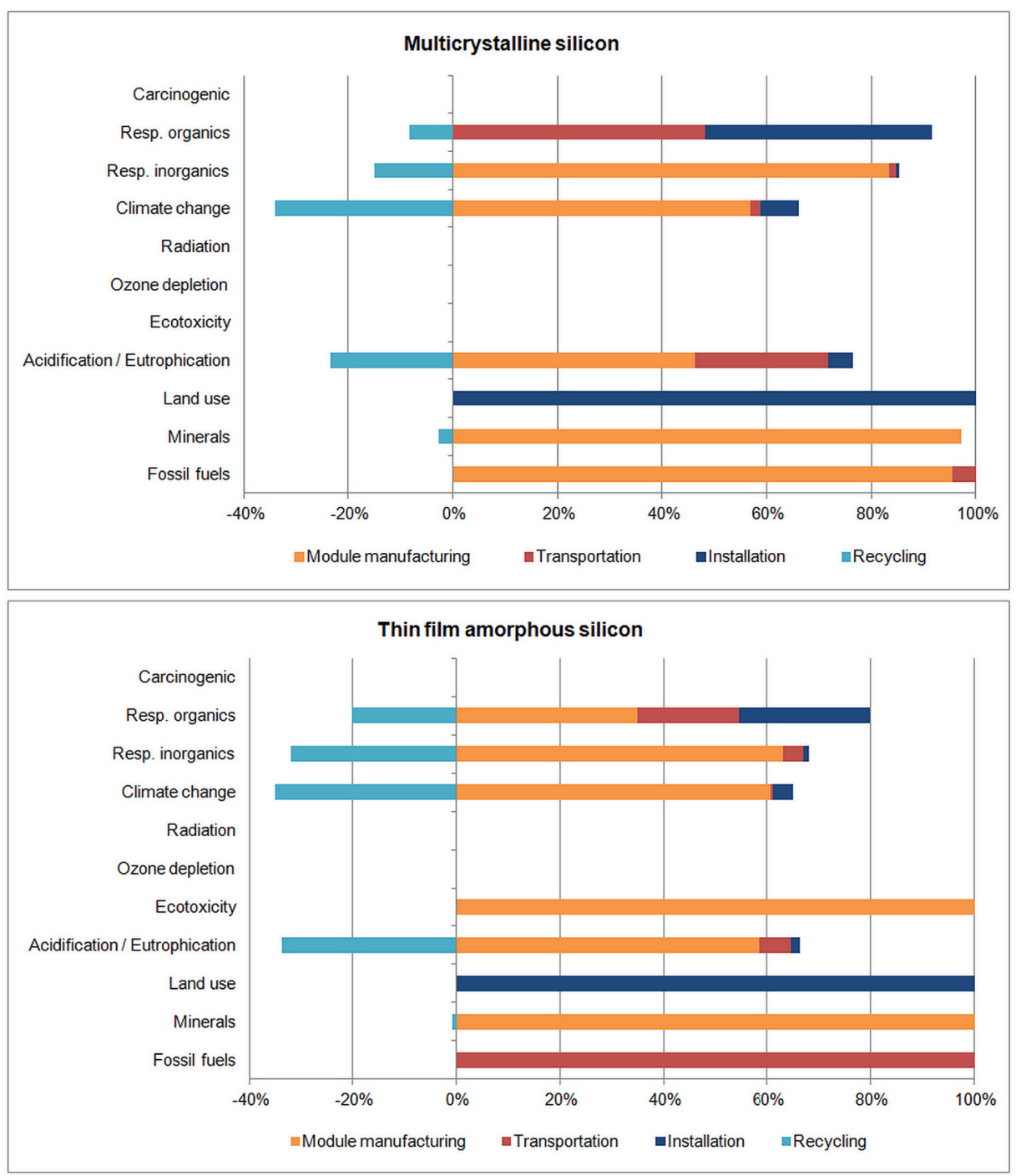

Figure 5. Characterised results of solar power generation process.

tively. It should be noted, however, that thin film is a developing technology, and manufacturers expect rapid improvements in the efficiency of their products. In the near future, efficiencies are predicted to rise to about $10-16 \%$ [Maehlum 2013]

Finally, there was a positive environmental impact when the solar cells where recycled at the end of their productive life. This was largely due to the energy saved when producing new cells using recycled wafers, which resulted in an energy saving of around a $1 / 3$. As Fig 6 shows, the greatest overall positive impact was on climate change, a consequence or recycling the thin film amorphous cells. The recycling of multicrystalline cells had the greatest impact upon the respiration of inorganic substances.

When analyzing the main impact categories for $1 \mathrm{kWh}$ of power generation, it can be seen that both power plants had an impact upon Human
Health, Ecosystem Quality and Resource Depletion. Overall, the main end-of-point impact category in the northern power plant was Resource Depletion, measuring $1.71 \mathrm{E}-03 \mathrm{Pt}$, because of the pollutant emissions from the multicrystalline cell manufacturing process. Regarding the central power plant, the main end-of-point impact category was Ecosystem Quality because of the vast amounts of arable land used to construct the thin film amorphous cell array during the installation stage, which measured 2.02E-03 Pt (See Fig. 7).

When the four stages of solar power generation were compared, the greatest environmental impact was clearly module manufacturing. This was true in both plants, although the environmental impact of the northern plant was higher than that of the central plant, which measured 2.84E$03 \mathrm{Pt}$ and 2.75E-03 Pt respectively. This was ostensibly due to the differing types of solar cell 

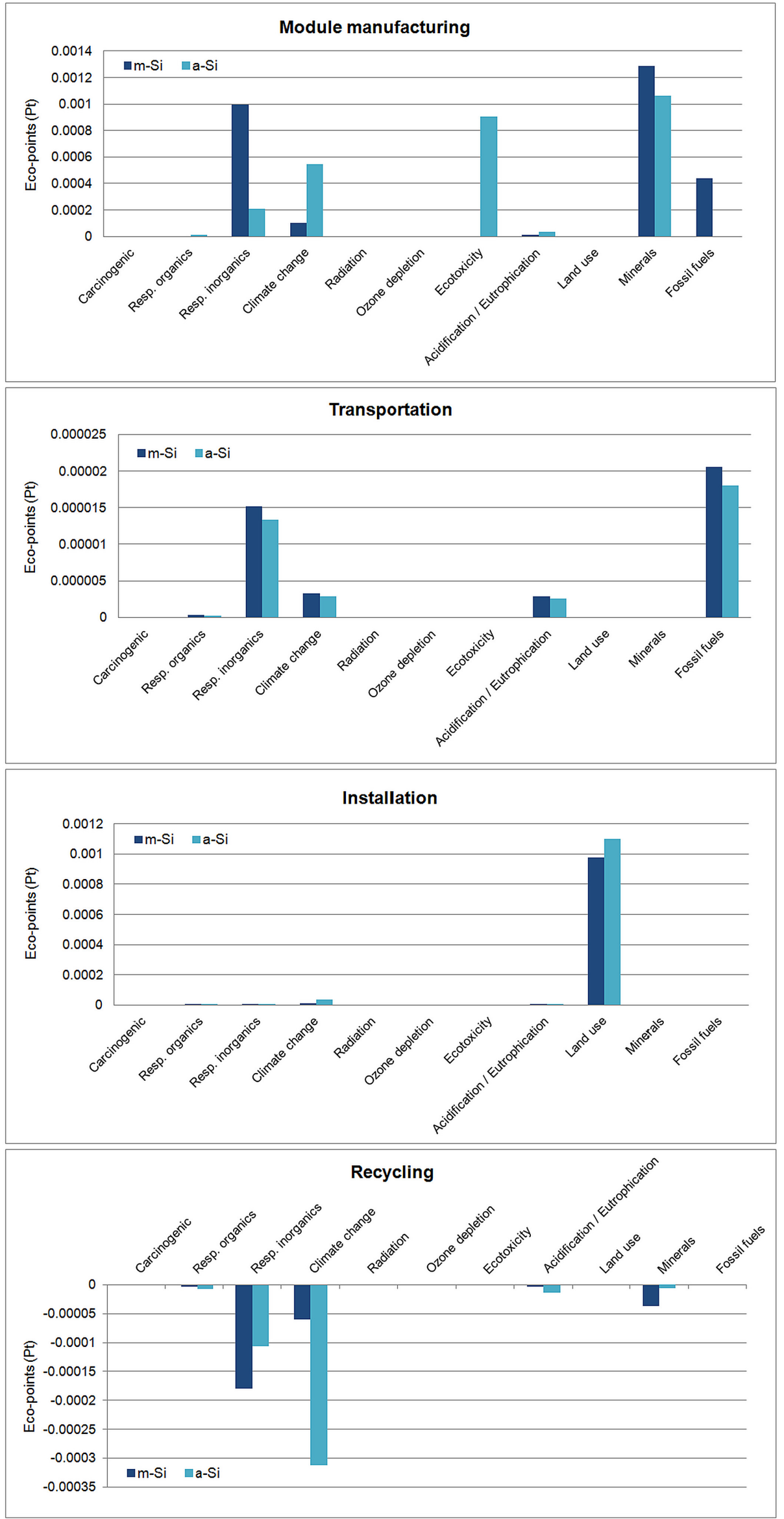

Figure 6. Impact categories from solar cell power plant in Thailand. 


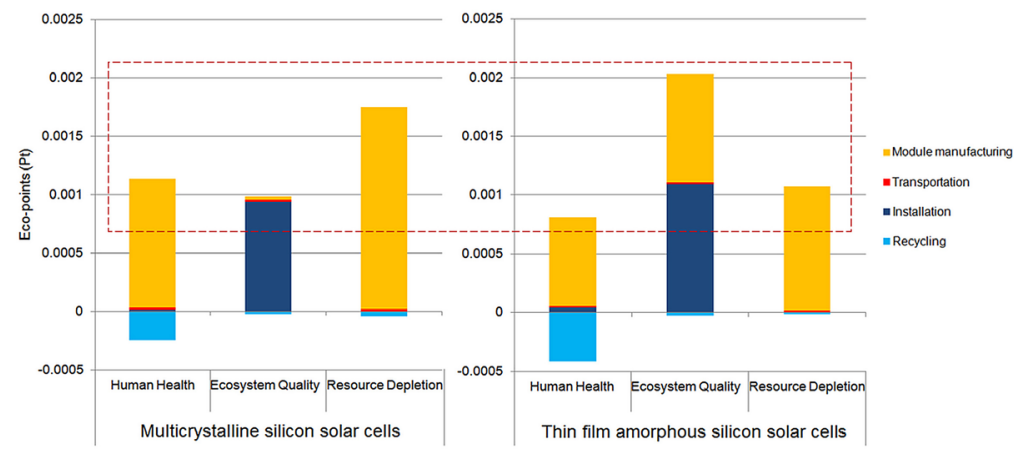

Figure 7. End-of-point impact categories from solar cell power plant in Thailand.

modules used, from which it can be concluded that the production of multicrystalline silicon solar cells has a higher environmental impact than that of thin film amorphous silicon solar cells. Whilst transportation was comparable between the two plants, they also differed significantly in the instillation stage, because of varying degrees of land use. Here, the lower conversion efficiency of the thin film amorphous silicon solar cells meant that much larger amounts of arable land were needed to construct the arrays and the central plant had a much greater impact than the northern plant. Lastly, it was possible to partly offset some of the environmental impact of both plants by recycling the solar cells at the end of their life. (See Fig. 8).

Overall, when all stages of the process were analyzed in totality (from manufacture to recycling), the environmental impact of the central plant, and therefore of the thin film amorphous silicon solar cells, was found to be the least damaging to the environment, with an overall impact factor measuring 3.49E-03 Pt. By contrast, the northern plant, and hence the use of multicrystalline silicon solar cells, was found to have a higher environmental impact of 3.59E-03 Pt.

\section{Comparison with power generation from various systems in Thailand}

Having assessed the environmental impact of two differing forms of solar power, this data was then compared with environmental impact data for more established non-renewable forms of power generation in Thailand - in particular, that of combined cycle power plants and thermal powered plants [Phumpradab et al. 2006]. Again, the functional unit was the generation of $1 \mathrm{kWh}$ of power. As can be seen from Fig. 9, the environmental impact of the solar plants was a tenth that of the non-renewable plants, both of which were heavily dependent on the burning of fossil fuels. Hence, both the combined cycle and thermal power plants had a very high impact upon Resource Depletion, in particular the extraction of fossil fuels.

\section{CONCLUSION}

This study has determined that power generation from solar energy, calculated using the functional unit of $1 \mathrm{kWh}$, had an environmental impact on Human Health, Ecosystem Quality and

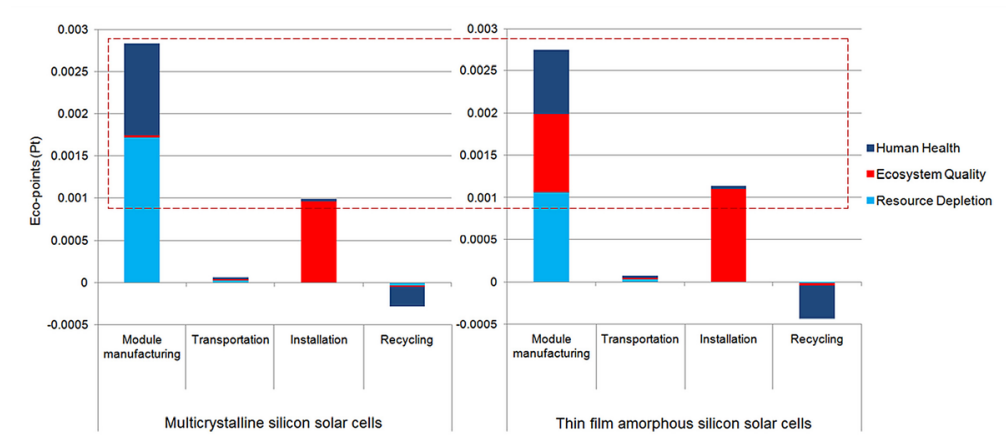

Figure 8. Environmental impact from solar cell power plant in Thailand. 


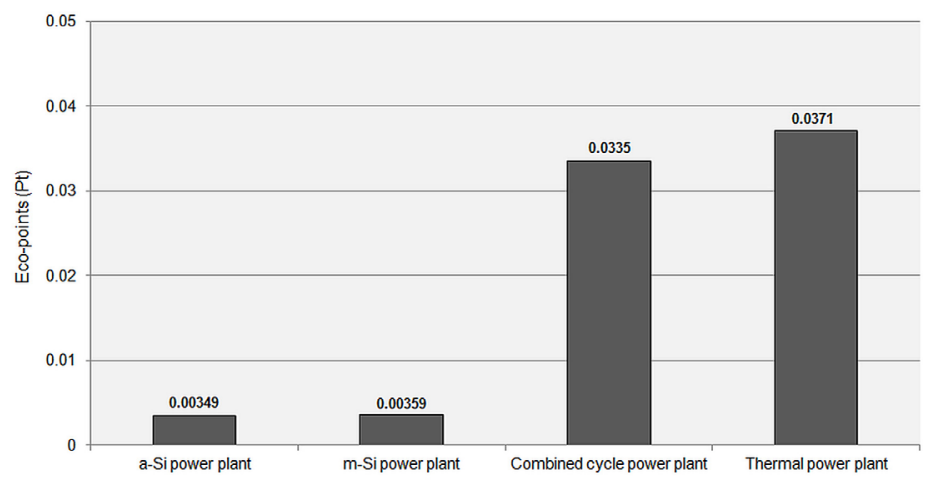

Figure 9. Total environmental impact comparison with the various power plants in Thailand.

Resource Depletion. This was true for both technologies of solar cell studied.

In the module manufacturing stage, Resource Depletion was the main end-of-point impact category. This was the result of the high quantities of aluminum and copper used in the module assembling process, the silicon and mineral oil used for wafer production and the quartz used for silicon production. The environmental impact of multicrystalline silicon solar cell manufacturing was higher than that of thin film amorphous silicon solar cells.

Analysis of the transportation stage showed Resource Depletion to again be the main end-ofpoint impact category, this time because of diesel consumption. The environmental impact of the northern plant was marginally higher because it was 37 kilometers further from the manufacturer.

The main end-of-point impact category of the installation stage was Ecosystem Quality, due to the large area needed upon which to construct the solar cell array. This was most significant in the case of the central plants, where the lower conversion efficiency of the thin film amorphous solar cells required a greater area of land to be covered.

Finally, during the recycling stage, it was possible to offset the impact of solar power generation to a certain degree by reusing the components of old solar cells, both in creating new photovoltaic cells (by reusing the wafer) and in creating new unrelated products (such as glass).

When the four main impact categories are compared, the module manufacturing stage was clearly the most detrimental to the environment - this was true for both types of solar cell module. Overall, the solar cell found to have the lowest impact upon the environment was the thin film amorphous solar cell, rather than the multicrystalline silicon cell (for $1 \mathrm{kWh}$ of power generation).
When the environmental impact of solar cell power plants is compared to traditional non-renewable power plants such as combined cycle and thermal power, it is abundantly clear that solar power is a much cleaner technology, with an environmental impact of around $10 \%$ that of burning fossil fuels, which has a very significant impact upon resource depletion. This would make the thin film amorphous silicon solar cell power plant the cleanest of the four forms of power generation studied, with the least impact upon the environment.

\section{Acknowledgements}

The authors would like to express their gratitude to the managers of both solar cell power plants involved in this study and their help in obtaining the survey data used and the Energy Policy and Planning Office (EPPO) for providing financial support to this research work.

\section{REFERENCES}

1. Alsema E.A., Wild-Scholten M.J., Fthenakis V.M. 2006. Environmental impacts of PV electricity generation-A critical comparison of energy supply options. $21^{\text {st }}$ European Photovoltaic Solar Energy Conference and Exhibition.

2. Anctil A., Fthenakis. 2012. Recyclability challenges in "abundant" material-based technologies. $27^{\text {th }}$ European Photovoltaic Solar Energy Conference and Exhibition.

3. Azapagic A. 1999. Life cycle assessment and its application to process selection design and optimization. Chemical Engineering Journal, 73, 1-21.

4. Chamsilpa M., Vorayos N., Katsiriroat K. 2010. Environmental impact analysis of solar cell power plant compared with fossil fuel power plants in Thailand. Asian Journal on Energy and Environment, 103-117. 
5. Davies S. 2013. The following is a short description on the various types of panels available and some of their characteristics. World Focus 1412 CC, 2007/000484/23.

6. DEDE. 2015. Alternative Energy Situation in Thailand 2015 (14th edition). Department of Alternative Energy Development and Efficiency, Bangkok.

7. Fraas L., Partain L. 2010. Solar cells and their applications second edition. Wiley, New Jersey.

8. Goedkoop M., Spriensma R. 2000. The Eco - indicator 99 - A damage oriented method for Life Cycle Impact Assessment. $2^{\text {nd }}$ ed., PRé Consultants b.v., Amersfoort.

9. Goedkoop M., Spriensma R., Müller-Wenk R., Hofstetter P., Köllner T., Mettier T., Braunschweig A., Frischknecht R., Van de Meent D., Rikken M., Breure T., Heijungs R., Lindeijer E., Sas H., Effting S. 2001. The Eco - indicator 99 - A damage oriented method for Life Cycle Impact Assessment. $3^{\text {rd }}$ ed., PRé Consultants b.v., Amersfoort.

10. Havelaar A. 2007. Methodological choices for calculating the disease burden and cost-of-illness of foodborne zoonoses in European countries. Med-Vet-Net Administration Bureau, Maisons-Alfort Cedex.

11. Hendrickson C., Horvath A., Joshi S., Lave L. B. 1998. Use of Economic Input-Output Models for Environmental Life Cycle Assessment. Environmental Science \& Technology.

12. Henryk M.S. 2011. Environmental impact of rail and road transport. Economic and Environmental Studies, 11, 405-421.

13. ISO 14040. 2006a. Environmental management-life cycle assessment-principles and framework. International Organization for Standardization, Geneva.

14. ISO 14042. 2000. Environmental management-life cycle assessment-life cycle impact assessment. International Organization for Standardization, Geneva.

15. ISO 14044. 2006b. Environmental management-life cycle assessment-requirements and guidelines. International Organization for Standardization, Geneva.

16. Jensen A.A., Hoffman L., Møller B.T., Schmidt A., Christiansen K., Elkington J., Dijk F.V. 1997. Lifecycle assessment (LCA) - a guide to approaches, experiences and information sources. European Environment Agency.

17. Khaenson W., Maneewan S., Punlek C., Chindaraksa S., Rachapradit N. 2016a. Life cycle assessment of power generation from solar energy in Thailand. Environmental Science and Sustainable Development, 223-229.

18. Khaenson W., Maneewan S., Punlek C. 2016b. Life cycle assessment of power generation from renewable energy in Thailand. GMSARN International Journal, 10 (4), 145-156.

19. Maehlum M.A. 2013. Amorphous Silicon Solar Panels. http://energyinformative.org/amorphoussilicon-solar-panels [Online].

20. Meyer L., Tsatsaronis G., Buchgeister J., Schebek L. 2009. Exergo environmental analysis for evaluation of the environmental impact of energy conversion system. Energy, 34, 75-89.
21. Monier V., Hestin M. 2011. Study on photovoltaic panels supplementing the impact assessment for a recast of the WEEE directive. http://ec.europa. eu/environment/waste/weee/pdf/Study\%20on $\% 20$ PVs\%20Bio\%20final.pdf [Online].

22. Müller A., Wambach K., Alsema E. 2005. Life cycle analysis of a solar module recycling process. $20^{\text {th }}$ European Photovoltaic Solar Energy Conference and Exhibition.

23. Netherlands Embassy in Bangkok. 2016. Solar Power in Thailand. Ministry of Foreign Affairs, Bangkok.

24. Olson C., Geerligs B., Goris M., Bennett I., Clynkke J. 2013. Current and future priorities for mass and material in silicon PV module recycling. $28^{\text {th }}$ European Photovoltaic Solar Energy Conference and Exhibition.

25. Phumpradab K., Thongbhakdi A., Shabbir H.G. 2006. Environmental assessment of electricity production from natural gas fired power plants. The $2^{\text {nd }}$ Joint International Conference on Sustainable Energy and Environment.

26. Phylipsen G.J.M., Alsema E.A. 1995. Environmental life cycle assessment of multicrystalline silicon solar cell modules. Netherlands Agency for Energy and the Environment, Sittard.

27. Reno M.L.G., Lora E.E.S., Palacio J.C.E., Venturini O.J., Buchgeister J., Almazan O. 2011. A LCA (life cycle assessment) of the methanol production from sugarcane bagasse. Energy, 36, 3716-3726.

28. Richard M.G. 2008. Solar Industry Creates Scheme to Recycle Solar panels in Europe. http:// www.treehugger.com/files/2008/05/solar-panelsrecycling-recycled-europe.php [Online].

29. Stoppato A. 2008. Life cycle assessment of photovoltaic electricity generation. Energy, 33, 224-232.

30. Terry C., Tanokkorn C. 2014. Thailand PV status report 2012-2013. Department of Alternative Energy Development and Efficiency, Bangkok.

31. Theodosiou C., Koroneos C., Moussiopoulos N. 2005. Alternative scenarios analysis concerning different types of fuels used for the coverage of the energy requirements of a typical apartment building in Thessaloniki, Greece. Part II: life cycle analysis. Building and Environment, 40, 1602-1610.

32. Tsuo Y.S., Wang T.H., Ciszek T.F. 1999. Crystalline-silicon solar cells for the 21 st century. The Electrochemical Society Annual Meeting.

33. Wambach K., Schlenker S., Müller A., Ramin-Marro D.V., Clyncke J., Gomez V., Hartleitner B., Rommel W. 2009. The voluntary take back system and industrial recycling of PV modules. 24 ${ }^{\text {th }}$ European Photovoltaic Solar Energy Conference and Exhibition.

34. Weidema B. 2000. Avoiding co-product allocation in life-cycle assessment. Journal of Industry Ecology, 4, 11-33.

35. Yue D., You F., Darling S.B. 2014. Domestic and overseas manufacturing scenarios of silicon-based photovoltaics: Life cycle energy and environmental comparative analysis. Solar Energy, 105, 669-678.

36. http://www.ertc.deqp.go.th/ertc/images/stories/ user/ct/ERTC20Y/CarbonLabel.pdf [Online]. 